\title{
The Protection of The Worker's Right During The Covid-19 In Central Java- Indonesia: Legality V. Reality
}

\author{
Diastama Anggita Ramadhan ${ }^{1}$, Rahayu Rahayu ${ }^{2}$, Pulung Widhi Hari Hananto ${ }^{3}$ \\ \{diastamaanggita@lecturer.undip.ac.id ${ }^{1}$, rahayu@ lecturer.undip.ac.id ${ }^{2}$, \\ pulungwidhiharihanan@lecturer.undip.ac.id $\left.{ }^{3}\right\}$ \\ Universitas Diponegoro, Semarang, Indonesia ${ }^{1}$, Universitas Diponegoro, Semarang, Indonesia ${ }^{2}$, \\ Universitas Diponegoro, Semarang, Indonesia ${ }^{3}$
}

\begin{abstract}
The global pandemic has had very significant implications for the global order and human life around the world. One of the serious policies faced is a huge loss in the domestic economic sector of each country, one of which is Indonesia. Many companies in Indonesia have made efficiency by laying off and suspended (housed). As a result, many workers' rights are not accommodated proportionally and are prone to law violations. In this paper, the writes would like to elaborate and harmonize the protection of worker's rights as impacted the Covid-19 in Central Java. Indonesia.
\end{abstract}

Keywords: The Protection, Right of Workers, Legality, Reality.

\section{Introduction}

The global phenomenon of Covid-19 pandemic is at the center of the world attention since its outbreak in the early months of 2020[1]. Per may 2020, this pandemic has continued to take over all segment of international segments, from the health crisis to the domestic economy. As the impact, almost every international communities had impacted by this pandemic. Many countries had released the urgent policies to boldly anticipate the spreading of COVID 19 instead imposed the travel ban and also declared the lockdown[2]. Due to this Pandemic and the pandemic global range from US\$ 2 Trillion to US\$ 4.1 Trillion or -2,3 to 4,8 of Global gross domestic economy[2]. In Indonesia, the Fiscal Agency Policy or BKF of Ministry of Finance estimates that the loss rate due to the Covid-19 pandemic in Indonesia will reach IDR 320 Trillion during the first quarter of 2020[3]. As the data above, Covid-19 has a large impact and serious attacks in economic sector not only in global spectrum but also the domestic economy.

The United Nations $(U N)$ had reported that states are at risk of disrespecting human rights in its precaution measures to prevent the spread of pandemic[4]. This encompasses various action such as extensive lockdowns, adopted to slow transmission of the virus, restrict by necessity freedom of movement and, in the process, freedom to enjoy many other human rights[4]. The efficiency measure and step taken by the state in face this pandemic indirectly affect the human right segments, one of them is the rights of workers.

In Indonesia, the implication of pandemic gives significant attacks to the domestic economic, especially the sector of company and labor matters. In this context both big company and local company has serious impact to handle this pandemic. As the result they 
release the policy to reduce their workers and labors. The National Development Planning Agency (hereinafter Bappenas) reports that the number of unemployed people in Indonesia is at risk of increasing due to the impact of Covid-19. Echoed by the Minister of National Development Planning (PPN) explained that the open unemployment rate is projected to increase by 4 million to 5.5 million in 2020[5]. Later, the Open Unemployment Rate in 2020 will reach $8.1-9.2$ percent. This number is far above the realization in 2019 which reached 5.28 percent. Meanwhile, in 2021 it is estimated that will reach 7.7 to 9.1 percent[5]. In Semarang, as the data collected per August by the Manpower Agencies stated that the unemployment rate in Semarang is 15.678 peoples[6]. the sector that lost the most workers were the trade, hospitality, manufacturing, construction, corporate services and accommodation sectors[6]. As the impact of this efficiency, many of worker and labors faced the termination of work and suspended (housed) by its former company.

\section{Literature Review}

\subsection{Definition and Legal Protection of The Worker}

Labor relations are regulated in Law No. 13 concerning Manpower (hereinafter referred to as the Manpower Act) which was ratified by the Government of the Republic of Indonesia, State Gazette of 2003 Number 39. UU. Employment separates the definition of the terminology of labor from labor. In Article 1 number 2 of the Law on Manpower, labor is defined as a person who is capable of doing work in order to produce goods and or services either to meet the needs of himself or the community. Meanwhile, a worker or laborer is everyone who works and receives wages or remuneration in any form. This terminology is too broadly demarcated because the context of the meaning of labor can be interpreted as all people who work for anyone, either individually, in a legal entity business association, or other entity by receiving wages or compensation in any form.

The meaning of wages in any form is often interpreted as money, but in fact it is possible for a worker to receive compensation in kind. The main point of setting the law. Employment is a working relationship between an employer and a worker that contains reciprocal rights and obligations. Labor rights are the obligations of business actors and vice versa. Rights and obligations are regulated in the work agreement and must be carried out by both parties properly. The forms of working relations that are facilitated in work agreements include work agreements; Unspecified time work agreement, Fixed Term Work Agreement (PKWTT); Company regulations; Collective labor agreement; Contracting Agreement.

The protection guarantee aims to provide law enforcement on the work relationship system without pressure from the strong to the weaker party. In the juridical arrangement in article 5 of the Law. Manpower guarantees protection by adhering to the principle of nondiscrimination, meaning that every worker has the right and the same opportunity to obtain a decent job and livelihood without distinguishing gender, ethnicity, race, religion, and political orientation according to the interests and abilities of the workforce concerned. including equal treatment of persons with disabilities. With this in mind, business actors are obliged to provide workers or laborers with rights and obligations regardless of gender, ethnicity, race, religion and political orientation as regulated in Article 6 of the Manpower law. The limitation of labor protection in the Manpower Act broadly includes: first, wage protection, welfare and social security. Second, the protection of occupational safety and health. third, legal protection to form and join unions; Workers / labor unions. Fourth, protection of the basic rights of workers 
/ laborers to bargain; with businessmen.

Wages are an important component in providing welfare guarantees for workers. This provision is explicitly regulated in article 1 point 30 which states that: wages are the rights of workers or laborers that are received and expressed in the form of money as compensation from employers or employers to workers or laborers who are determined and paid according to a work agreement, agreement, or legislation. - legislation, including allowances for workers or laborers and their families for a job and or services that have been or will be performed. The authority to determine the provision of minimum wages is determined by the Government, which is determined by the Regional Government concerned.

Apart from material legal protection, workers also have the basic rights of their workers to negotiate with employers. The manpower law facilitates communication and negotiation for workers / laborers with employers, namely through the existence of a bipartite institution. The purpose of establishing a bipartite institution is to resolve disputes between workers / laborers and employers. The last basic right of a worker is to form and become a member of a trade / labor union found in Article 104 of Manpower Law , there are states :"Every worker/laborer has the right to form and become a member of a trade union / labor union". Workers / laborers who are members of a trade / labor union have the right to manage finances and be accountable for the organization's finances, including for strike funds. "

\subsection{The factual data of worker in Central Java: fact vs reality}

as stated in introduction, the spread of the Covid-19 in Indonesia is a serious matter that cannot be underestimated because within 15 (fifteen) days from March 2, 2020 to the end of August 2020, 6759 people have been infected and 25 of them have died[7]. The Indonesian government has determined the status of the spread of the corona virus as a national disaster since March 15, 2020. Workers have felt the implications of the outbreak of the Covid-19 pandemic in the labor sector. Workers' wages are only calculated per hour, work only 15 (fifteen) days a month, providing unpaid leave until termination of employment. The outbreak of the corona virus has also resulted in reduced shopping center visitors and choked delivery of goods. Unilateral actions taken by companies against workers will cause new legal problems, in which workers / workers are the most disadvantaged party. Daily workers, contract workers and outsourcing workers who have the weakest bargaining position and are easily dismissed. Based on data from the Ministry of Manpower (Kemnaker) as of April 7, 2020, as a result of the Covid-19 pandemic, there were 39,977 companies in the formal sector that chose to lay off and lay off their workers. In total there are 1,010,579 workers affected by this. In detail, 873,090 workers from 17,224 companies were laid off, while 137,489 workers were laid off from 22,753 companies. Meanwhile, the number of companies and workers affected in the informal sector was 34,453 companies and 189,452 workers[8].

In refer to the Right to Work and a Decent Livelihood, it is fitting for the Government to ensure that there is no termination of employment by companies and the provision of decent wages in accordance with the provisions of the prevailing laws and regulations. The wage system has been regulated in Article 90 of Manpower Law, which states that "employers are prohibited from paying wages lower than the minimum wages as referred to in Article 89". It is clear that employers are prohibited from paying workers' wages below the minimum wage as long as there is no wage suspension and continue to pay wages in accordance with the provisions of the prevailing laws and regulations. Likewise, Article 151 paragraph (1) of the Manpower Law states that "employers, workers / laborers, trade / labor unions, and the government must make every effort to prevent termination of employment." Thus, the government has an obligation to make efforts so that nothing happens. laborers / workers who 
have experienced termination of employment.

The city of Semarang, which is the center of the economy in Central Java Province, has also experienced an economic downturn and many local business actors have adopted unpopular business policies, namely the termination of employment relationships and "laying off" workers for a while. According to data from the Semarang City Manpower Office, it is recorded that 84 companies registered and affected by Covid-19 have terminated employment and "laid off their employees" for an indefinite period of time. As a result, 7,157 people became unemployed due to layoffs by the company and 8,521 workers who were dismissed without a clear time limit and without getting benefits[9].

However, the provisions of norms regulated in statutory regulations (Law in books) often experience differences with the application of law in a sociological sense (Law in Action). The spread of the COVID-19 pandemic throughout Indonesia indirectly affects productivity performance, company finances and employers 'obligations to meet operational costs, especially workers' wages. The work from home policy launched by the Government actually adds to the burden on companies, because not all types of business can be done from the residence of each worker. This condition encourages a number of them to practice unpaid leave (leaving workers, but not paid), laying off workers, and even terminating employment (layoffs) by employers unilaterally in order to reduce the burden on their business. The employment relationship is generally based on a work agreement between the business actor and the worker, which is an agreement in which the first party, the worker binds himself to another party, the employer to work for wages and the employer states his ability to employ the worker by paying wages[10].

The difficulties experienced by entrepreneurs due to the COVID-19 pandemic, which caused a condition called Force majeure, were used by business actors as an excuse to terminate the work relations of their workers. However, this cannot immediately result in layoffs, even though the Covid-19 pandemic is included in force majeure. In the provisions of Article 164 of the Manpower Law, it is stated that: "Employers can terminate employment of workers / laborers because the company is closed because the company has suffered continuous losses for 2 (two) years, or a force majeure, provided that the worker / laborer is entitled to severance pay amounting to 1 (one) time the provisions of Article 156 paragraph (2) the reward pay for the work period of 1 (one) time the provisions of Article 156 paragraph (3) and compensation for rights in accordance with the provisions of Article 156 paragraph (4). "

Based on the provisions above, companies can actually lay off on the grounds of the Covid-19 pandemic as a form of force majeure. Although the Manpower Act does not explain the definition of force majeure. However, face-to-face business actors are obliged to pay attention to the welfare of their workers by continuing to provide severance pay, long service reward and compensation money equal to 1 time the value of each of the components above. When viewed in terms of the duration of the event, the corona pandemic is included in a temporary force majeure, considering that the inability of entrepreneurs to carry out their obligations is only temporary until normal conditions. This is supported by the Government's policy which has determined the corona pandemic as a national disaster and the issuance of several legal policies that can strengthen employers' reasons for making the corona pandemic a basis / reason that creates force majeure. In this regard, it can be explicitly stated that the corona pandemic can be categorized as a national non-natural disaster which can be classified into a temporary force majeure. 


\section{Research Method}

This article is a result of research with the type of socio-legal research. The approach used in this paper is a statutory approach. The technique of collecting legal materials in this study was carried out by using literature study techniques and interviews with related sources according to their competence. This research uses the deductive legal material analysis method, in which the legal materials that have been collected are classified and then conclusions are drawn from general matters into specific things.

\section{Result and Discussion}

\subsection{The sector hit the most and status during the pandemic}

The Covid-19 pandemic has affected all sectors around the world. One of the sector hardest hit by the Covid-19 pandemic is the economic sector. The stagnation of the economy has made many companies unable to avoid efficiency which has an impact on reduced employment opportunities for workers in various sectors.

As one of the areas that is the production base in Indonesia, Central Java Province is also affected by this pandemic. This can be seen from the Central Java Statistics Agency (BPS) report which states that the Trade Balance experienced a deficit of $4.80 \%$ in February 2020 compared to January 2020.3 This is one of the impacts of the social distancing policy implemented by the government obliging several activities to stop, including school and workplace[11]. Referring to the Regulation of the Minister of Health Number 9 of 2020, there are only a few fields that are allowed to continue working, namely:[12]

1. Services related to defense and security;

2. Business in the field of food needs;

3. Business in the field of fuel oil and gas;

4. Health services;

5. Business in the economic, banking and financial services sectors;

6. Business in logistics and distribution;

7. Business in the field of telecommunications;

8. Business in retail that sells basic needs of the community.

Based on research conducted by the author, data released by the Semarang City Manpower Office, in Semarang City itself as the capital of Central Java Province, the number of companies and the number of workers affected by the Covid-19 Pandemic are as follows:[13]

Table 1. Registered Company Data at the Semarang City Manpower Office

$\begin{array}{cc}\text { Number of } & \text { The Amount of } \\ \text { the Company } & \text { Labour }\end{array}$




\begin{tabular}{lcc}
\hline Registered & 4.083 & 230.099 \\
Affected by the Pandemic & 83 & 15.934 \\
Got lay off by the Company & 7.413 \\
Got released off by the Company & 8.521 \\
\hline
\end{tabular}

About $4 \%$ of the total number of companies that registered themselves with the Semarang City Manpower Office declared themselves to be companies affected by the Covid19 Pandemic. From the point of view of the number of companies this figure does not seem that significant. This is inversely proportional if the impact of this pandemic is seen from the point of view of the number of workers affected. The number of workers affected by the Covid-19 Pandemic in Semarang City was 15,934, with details of 7,413 people losing their jobs and the remaining 8,521 people who were dismissed by their companies because the company could not run operations. Judging from the types of businesses affected, several types of businesses most affected by this pandemic include tourism, garment, manufacturing and other businesses engaged in the service sector[13].

\subsection{The gap between the protection of worker's right as stipulated on the Law and the reality happens}

The conditions of the Covid-19 pandemic have forced many companies to make efficiency because they are unable to adapt to existing conditions. Worse, companies that no longer have some space to do their business either because they do not have permission to continue to do business or are affected by the downturn in the economy are forced to stop all their business activities and declare themselves bankrupt[14]. Moreover, regarding the rights of workers affected by termination of employment, in Law Number 13 of 2003 concerning Manpower, there are several stages that can be taken when an action termination of employment (PHK) occurs, including:[14]

1. Article 93 paragraph (3) states that efforts are made to negotiate between the parties, both employers and workers and agree on the payment of workers' wages prior to dismissal.

2. Article 164 paragraph (1) states that Employers can terminate their employment by giving the right in the form of severance pay which is calculated from the working period based on Article 156 of the Law.

3. 3.Article 164 paragraph (3) states that in situations where companies are forced to perform efficiency due to the Covid-19 Pandemic, employers are required to provide 2x severance pay from the working period as stated in Article 156 of the Law.

The problem is the ability of companies or employers to fulfill the rights of workers affected by this pandemic. Company bankruptcy is accompanied by a decline in the company's ability to carry out its obligations, including obligations towards employees who are either still working or have been terminated. The Government of the Republic of Indonesia itself has 
attempted to provide relief to companies through the Minister of Manpower Circular Number M / 3 / HK.04 / III / 2020 concerning Protection of Workers / Laborers and Business Continuity in the Context of Preventing and Overcoming Covid-19[15]. The letter provides an appeal to employers to renegotiate the wages that will be given to workers.

\subsection{The mechanism and durable solution to protect the right of impacted workers.}

Various efforts have been made by the government to protect workers' rights in the conditions of the Covid-19 Pandemic, namely by providing concessions in various aspects. This leeway given is expected to make it easier for companies or businesses in various sectors to be able to continue their business when this pandemic has ended, some of the efforts that have been made by the Government of Indonesia include:

1. Tax Relaxation by the Ministry of Finance for business actors through the Decree of the Director General of Taxes Number KEP-156 / PJ / 2020 concerning Taxation Policies Regarding the Spread of the Corona Virus Outbreak 2019;[16]

2. Providing direct cash assistance for workers with incomes below 5 million rupiah through the Minister of Manpower Regulation Number 14 of 2020 concerning Guidelines for Providing Government Assistance in the Form of Salary / Wage Subsidies for Workers / Laborers in Handling the Impact of the Covid-19 Pandemic.[17]

However, further than that, workers need guarantees to be able to continue working and earn income sustainably so that they can earn a decent income. Based on the results of the research carried out, the researchers initiated the need for synergy between ministries to prepare job nets for workers / workers affected by the Covid-19 pandemic while still taking into account the feasibility of wages that workers will receive.

\section{Conclusion}

This research reveals that the Covid-19 Pandemic has had an impact on Indonesia's economic conditions, especially in Central Java Province. The disruption in the economy has resulted in many companies being forced to make efficiency or declaring themselves bankrupt due to the conditions that have occurred. In any case, workers' rights must be protected. Creating a job net for workers / laborers affected by this pandemic is very urgent to be implemented immediately. Ministries and related stakeholders must work together to immediately resolve the rights of workers affected by the Covid-19 pandemic.

\section{Acknowledgement}

Acknowledgment. The author would like to credit and thanks to Universitas Diponegoro, Semarang. Another thanks to The International Conference on Environmental and Technology of Law Business and Education on Post Covid-19 in edition 2020, in order to review, advice and accept this paper. Next, we would like to thank the Manpower Agency of Semarang who's giving the data was used by the author as reference material that serves to provide the supporting data for analysis of this article. As the result, this study is highly qualification and can be published for the advancement of science, especially in Labor Law, Covid-19 Studies 
and Sociology of Law.

\section{Reference}

[1] World Health Organization, "Novel Coronavirus (2019-nCoV): situation report," 2020.

[2] P. W. H. Hananto, "Does China can be sued for the Global Pandemic?," Adm. law Governnace J., vol. 3, no. 2, 2020.

[3] Kementerian Keuangan, "Minister of Finance Report," 2020.

[4] United Nations, "COVID-19 and Human Rights: We are all in this together," 2020.

[5] Bappenas, "the Impact of Corona, The Number of Unemployment Could Reach 12.7 Million in 2021," . https://money.kompas.com/read/2020/06/22/163400126/dampakcorona-jumlah-pengangguran-bisa-tembus-12-7-juta-di-2021 ? page =all, 2020. .

[6] The Report of Manpower Agency of Semarang, "data collected per August by the Manpower Agencies."

[7] The Data of Covid-19, “Covid-19," https://covid19.go.id/pada, 2020. .

[8] Kementerian Tenaga Kerja, "Data PHK karyawan terdampak covid 19 Per April 2020,” https://kemnaker.go.id/, 2020. .

[9] Dinas Ketenagakerjaan Kota Semarang, "Data Perusahaan yang Terdampak Covid 19 Terdaftar Dinas Ketenagakerjaan per 30 Augustus 2020," http://naker.semarangkota.go.id/2020/, 2020. .

[10] Z. Asikin and Dkk, Dasar-Dasar Hukum Perburuhan. Jakarta: Rajagrafindo Persada, 2004.

[11] Indonesia, Government Regulation Number 21 of 2020 concerning Large-Scale Social Restrictions in the Context of Handling Corona Virus Disease 2019 (Covid-19). 2020.

[12] Kementerian Kesehatan, ), Regulation of the Minister of Health Number 9 of 2020 concerning Guidelines for Large-Scale Social Limits in the Plan for the Acceleration of Handling Corona Virus Disease 2019 (Covid-19). 2020.

[13] Semarang City Manpower Office, "Registered Company Data at the Semarang City Manpower Office," 2020.

[14] Khairunissa, I. Indriani, Nurhayati, and T. Hanafi Setiawan, Achmad Anedea, "Membangun Mental Positif Para Pekerja dan Penyuluhan Hak-Hak Pekerja Yang di PHK atau yang Mendapatkan Dampak Covid-19," DEDIKASI, vol. 1, no. 2, p. 6, 2020.

[15] Kementerian Tenaga Kerja, Surat Edaran Menteri Ketenagakerjaan Nomor M/3/HK.04/III/2020 tentang Perlindungan Pekerja/Buruh dan Kelangsungan Usaha Dalam Rangka Pencegahan dan Penanggulangan Covid-19. 2020.

[16] Decree of the Director General of Taxes Number KEP-156 / PJ / 2020 concerning Taxation Policies Regarding the Spread of the Corona Virus Outbreak 2019. 2020.

[17] Minister of Manpower Regulation Number 14 of 2020 concerning Guidelines for Providing Government Assistance in the Form of Salary / Wage Subsidies for Workers / Laborers in Handling the Impact of the Covid-19 Pandemic. . 